\title{
Lung cancer in lifelong non-smokers
}

\author{
S Capewell, R Sankaran, D Lamb, M McIntyre, M F Sudlow \\ on behalf of the Edinburgh Lung Cancer Group
}

\begin{abstract}
The Edinburgh Lung Cancer Group registered 3070 new patients with lung cancer in the five years 1981-5 from a catchment population of 950000 . After review only $74(2 \%)$ were classified as lifelong non-smokers. They differed significantly from the 2996 smokers with lung cancer in that far more were female $(77 \% v$ $26 \%$ ) and their mean age was higher (75.4 $v$ 68.0 years). More were in the worst Karnofsky performance categories and fewer patients underwent surgery. The stages of disease were similarly distributed in the two groups and the five year survival was equally poor (5\%). Histological cell type was determined in 59 of the 74 patients. All histological cell types were present. More non-smokers had adenocarcinoma than smokers $(42 \%$ $v 13 \%$ ) and fewer had squamous cell carcinoma $(32 \%, v 49 \%)$ or small cell carcinoma $(15 \% v 24 \%)$. Lung cancer in lifelong non-smokers is uncommon and the diagnosis should therefore always be questioned.
\end{abstract}

The association between lung cancer and cigarette smoking was first reported 40 years $\mathrm{ago}^{12}$ and a dose-response relationship has been found repeatedly since then. ${ }^{3}$ In more recent series of lung cancer patients lifelong non-smokers accounted for only $2-5 \%$ of the total. ${ }^{34}$ Doll and Peto have concluded that smoking now accounts for $95 \%$ of lung cancers in developed countries. ${ }^{5}$

Information on British non-smokers with lung cancer is scanty and conflicts to some extent with findings reported from the United States and elsewhere; the relative frequencies of cell types in smokers and non-smokers in particular are disputed. In the 1950s Kreyberg and colleagues suggested that in men four out of five squamous cell and anaplastic carcinomas ("group I") were due to smoking, whereas adenocarcinoma and alveolar cell carcinoma ("group II") were unrelated. ${ }^{67}$ Support for the Kreyberg hypothesis was subsequently provided by the finding of a smoking dose-response relationship for both small cell carcinoma ${ }^{89}$ and squamous cell carcinoma, ${ }^{10}$ both group I tumours. Furthermore, a higher proportion of adenocarcinoma (31-85\%) was observed in series of non-smokers than in smokers with lung cancer in both developed ${ }^{11-14}$ and developing countries. ${ }^{15}$
The Kreyberg hypothesis has been increasingly criticised, however, for being simplistic. $^{81012131617}$ Substantial numbers of "Kreyberg group I" tumours have been reported in non-smokers, ${ }^{18}$ a dose-response relationship with smoking has been observed for adenocarcinoma, a group II cell type, ${ }^{10}$ and most adenocarcinomas occur in smokers. ${ }^{4}$ Additional criticism has been directed at the incomplete smoking histories in some of the earlier papers ${ }^{41213}$ and the wide variations in the percentage of lifelong non-smokers in lung cancer series from developed countries (from $1 \%$ to $5 \%$ in men and from $13 \%$ to $41 \%$ in women). ${ }^{411} 11_{19}^{19}$ In contrast, the high proportion of women in various series of non-smokers with lung cancer has been fairly consistent, ranging from $62 \%$ to $79 \%$. $^{411141920}$

Although lung cancer now kills over 40000 patients each year in the United Kingdom ${ }^{21} 22$ there is little recent information on nonsmokers with lung cancer. The Edinburgh Lung Cancer Group was formed in $1980^{23}$ and members serve a catchment population of about 950000 in south east Scotland. ${ }^{24}$ We have reviewed all the non-smokers with lung cancer seen during a recent five year period.

\section{Methods}

All patients with newly diagnosed lung cancer seen by the members of the Edinburgh Lung Cancer Group from 1981 to 1985 were recorded prospectively on a standardised registration form. Details included age, sex, occupation, smoking history, and performance score (Karnofsky index). Disease was staged according to the TNM system, ${ }^{25}$ on the basis initially of clinical and radiological features, supplemented by results of laboratory investigations. The diagnosis of lung cancer was based on histological or cytological evidence in $81 \%$ of cases or, in the absence of a pathological specimen, on clear clinical and radiological appearances. The treatment for each patient was also noted: surgery, palliative (1800-2200 CGy) or radical (4250-5740 CGy) radiotherapy, chemotherapy, or symptomatic treatment only.

All 99 patients originally classified as nonsmokers ${ }^{24}$ were reviewed on the basis of case notes, referral letters from general practitioners, nursing records, and postmortem information. These were scrutinised to satisfy the strict definition of a "lifelong non smoker"one who had never regularly smoked cigarettes, cigars, pipes, or any other form of tobacco. Where available pathological material 
from these patients was reviewed by two pathologists (DL and $\mathrm{MMcI}$ ) independently without any clinical information. All specimens were assessed in the light of agreed diagnostic criteria, based on a revised and updated version of the World Health Organisation classification, and the findings were recorded on an updated Medical Research Council proforma. ${ }^{26}$ The two pathologist's opinions were then compared and reviewed together with the original reports. Clinical and histological features in the smokers and non-smokers with lung cancer were compared by means of the $\chi^{2}$ test or Student's $t$ test as appropriate.

\section{Results}

The total number of new patients with lung cancer registered during the five completed years $1981-5$ was 3070 . The 99 patients originally classified as non-smokers were reviewed and 25 were subsequently excluded: 17 patients had smoked previously and been registered erroneously as non-smokers, and for one demented patient smoking history was not recorded in any document; four patients were subsequently found to have metastases from an extrathoracic primary tumour (breast in two cases, bladder, and prostate), and three further patients had other forms of thoracic malignancy at necropsy (one lymphoma, one angiosarcoma, and one mesothelioma).

The remaining 74 patients were then classified as lifelong non-smokers with primary lung cancer. The clinical diagnosis of lung cancer was originally confirmed by pathological material in 59 of the 74 non-smokers $(80 \%)$. Tissue was obtained by fibreoptic bronchoscopy with bronchial biopsy in 29 patients; by thoracotomy, lymph node biopsy, liver biopsy, or pleural biopsy in 15 patients, and from cytological material in a further 15 (sputum in 10 , pleural fluid in 4 , and a lymph node aspirate in 1 ). In the remaining 15 patients review of the

$\%$ of

patients

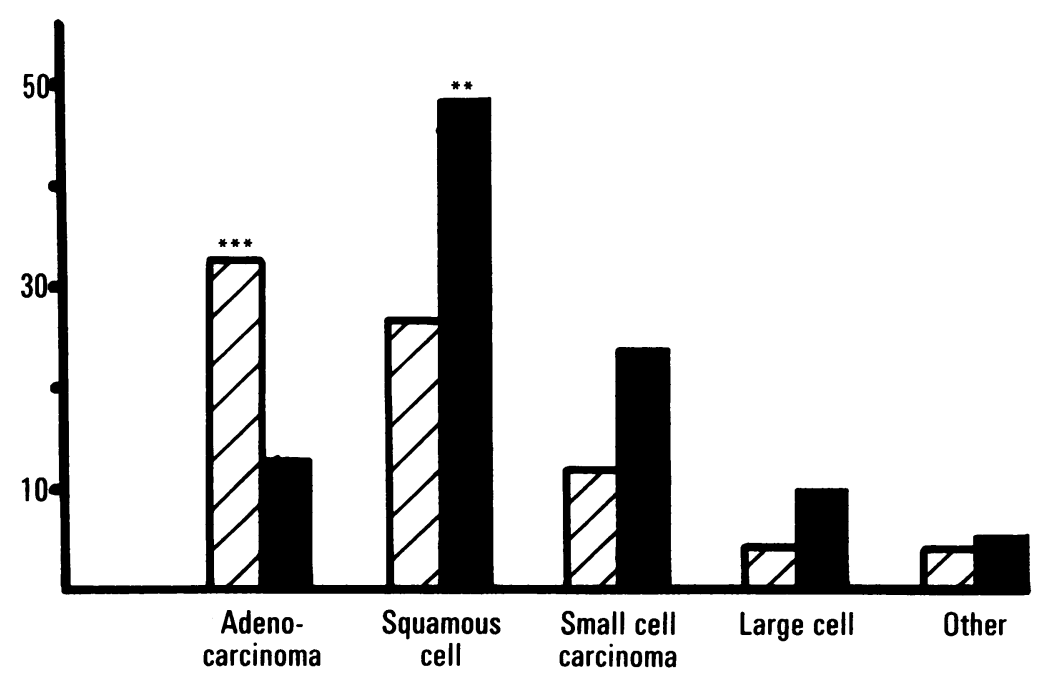

Comparison of histological cell types in 74 non-smokers (cross hatched columns) and 2996 smokers (solid columns). ${ }^{\star \star} p<0.01 ;{ }^{\star \star \star} \mathrm{p}<0.001$ clinical and radiological features strongly suggested primary lung cancer. Pathological confirmation of lung cancer was obtained in an identical proportion ( $80 \%$ ) of the 2996 patients in the smoking group.

The 74 non-smokers differed significantly from the 2996 smokers in several clinical features. Far more non-smokers were female (54: $77 \%$ v $23 \%$ in smokers, $\mathrm{p}<0.001$ ) and their mean age was 75.4 (range 28-99) years compared with 68 years in the smokers $(\mathrm{p}<0.05)$. Significantly more non-smokers were in the worst Karnofsky performance categories, $10-60(36 \% v 26 \%$, p < 0.05), and correspondingly fewer underwent surgery $(10 \% v 19 \%, \mathrm{p}<0.05)$. The stages of disease at the time of diagnosis were similar in the two groups $(62 \%$ v $58 \%$ stage III), and five year survival was equally poor $(4 / 74,5 \% v 7 \%)$.

Histological cell type was known for 59 of the 74 non-smoking patients. All cell types were represented. Adenocarcinoma was far more common than in the 2996 smokers, being present in 25 patients $(42 \% v 13 \%, \mathrm{p}<0.001)$. The non-smokers had correspondingly less squamous carcinoma ( 19 patients, $32 \% v 49 \%$, $\mathrm{p}<0.01)$ and slightly less small cell carcinoma (nine patients, $15 \%$ v $24 \%, \mathrm{p}=0.08$ ), large cell carcinoma (three patients, $5 \% v 10 \%$ ), and other types of carcinoma (three patients, $5 \% v$ $5 \%$ )-see figure.

\section{Discussion}

Lung cancer in lifelong non-smokers is uncommon and represented only $2 \%$ of this prospective series of some 3000 patients. Non-smokers accounted for $0.7 \%$ of the men with lung cancer and $6.7 \%$ of the women; these figures are lower than in most earlier studies. ${ }^{911}{ }^{114}$ Thus in south east Scotland, and by implication elsewhere in the United Kingdom, smoking may now account for over $99 \%$ of lung cancers in men and over $90 \%$ in women. The role of other factors, notably occupational exposure to carcinogens, which may interact with the effects of smoking, is not clear. These percentages might increase further if figures for lung cancer due to passive smoking were also included. ${ }^{527} 28$ The message for lung cancer prevention is clear.

Although three quarters of our non-smokers were women as in previous series, ${ }^{14}{ }^{19}$ our nonsmoking patients differed in being somewhat older and in having correspondingly worse performance scores, lower surgical resection rates, and a five year survival rate of only $5 \%$ compared with $7 \%$ in smokers. ${ }^{29}$ No occupational or domestic exposure to other recognised carcinogens had been recorded in these non-smoking patients. The female nonsmokers in Kabat's series more often had a past history of pneumonia and three times as many had worked in textile industries as controls. ${ }^{14}$ The previously high prevalence of tuberculosis in south east Scotland is not likely to be a factor because the contribution of tuberculosis scars to the incidence of lung cancer ("scar cancers") is now considered negligible. ${ }^{30} 31$ The importance of passive smoking, however, is being increasingly appreciated. ${ }^{27}{ }^{32}$ Wald suggested 
Table Summary of series of non-smokers with lung cancer

\begin{tabular}{|c|c|c|c|c|c|c|c|c|}
\hline \multirow[b]{2}{*}{ Study } & \multirow[b]{2}{*}{$\begin{array}{l}\text { Total } \\
\text { number }\end{array}$} & \multirow[b]{2}{*}{$\begin{array}{l}\text { Non-smokers } \\
(\text { No }(\%))\end{array}$} & \multirow{2}{*}{$\begin{array}{l}\text { Smoking } \\
\text { history } \\
\text { ascertained } \\
(\%)\end{array}$} & \multicolumn{4}{|c|}{ Cell type (No (\%)) } & \multirow[b]{2}{*}{ Comments } \\
\hline & & & & $\begin{array}{l}\text { Adeno- } \\
\text { carcinoma }\end{array}$ & $\begin{array}{l}\text { Squamous } \\
\text { carcinoma }\end{array}$ & $\begin{array}{l}\text { Small cell } \\
\text { carcinoma }\end{array}$ & Other & \\
\hline $\begin{array}{l}\text { This } \\
\text { study }\end{array}$ & $\begin{array}{l}3070 \\
\text { Male } \\
\text { Female } \\
\text { Female/male }\end{array}$ & $\begin{array}{cl}74 & 2 \% \\
20 & 0 \cdot 7 \% \\
54 & 6 \cdot 7 \% \\
77 \%\end{array}$ & $98 \cdot 6$ & $25(42)$ & $19(32)$ & $9(15)$ & $6(11)$ & See text \\
\hline $\begin{array}{c}\text { Kabat } \\
1984\end{array}$ & $\begin{array}{l}2668 \\
\text { Male } 1919 \\
\text { Female } 749 \\
\text { Female/male }\end{array}$ & $\begin{array}{c}1345 \% \\
371 \cdot 9 \% \\
9713 \% \\
72 \%\end{array}$ & $? 100$ & $92(69)$ & $29(22)$ & $9(7)$ & $4(3)$ & $\begin{array}{l}\text { Mean age men } 54 \text { years, women } 62 \\
\text { years }\end{array}$ \\
\hline $\begin{array}{l}\text { Beamish } \\
1975\end{array}$ & $\begin{array}{l}1145 \\
\text { Male } 915 \\
\text { Female } 230\end{array}$ & $6042 \%$ & ? 78 & $\begin{array}{l}\text { Kreyberg II } \\
35 / 60(58)\end{array}$ & & $\begin{array}{l}\text { Kreyberg I } \\
25 / 60(42)\end{array}$ & & $\begin{array}{l}\text { Selected group. Used Kreyberg } \\
\text { classification not cell typing }\end{array}$ \\
\hline $\begin{array}{c}\text { Vincent } \\
1977\end{array}$ & $\begin{array}{l}1682 \\
\text { Male } 1404 \\
\text { Female 278 } \\
\text { Female/male }\end{array}$ & $\begin{array}{cc}60 & 3 \cdot 6 \% \\
24 & 1 \cdot 7 \% \\
38 & 14 \% \\
63 \%\end{array}$ & 76 & $28(46)$ & $14(23)$ & $4(7)$ & $16(27)$ & Pathology series \\
\hline $\begin{array}{c}\text { Cooper } \\
1968\end{array}$ & $\begin{array}{l}1372 \\
\text { Male } 1250 \\
\text { Female } 122 \\
\text { Female/male }\end{array}$ & $\begin{array}{c}634 \cdot 6 \% \\
131 \% \\
5041 \% \\
79 \%\end{array}$ & ?100 & $40(63)$ & $16(25)$ & $7(11)$ & - & Pathology series. All slides reviewed \\
\hline $\begin{array}{l}\text { Wynder } \\
1967\end{array}$ & $\begin{array}{l}465 \\
\text { Male } 401 \\
\text { Female } 64 \\
\text { Female/male }\end{array}$ & $\begin{array}{rl}34 & 7 \cdot 3 \% \\
8 & 2 \% \\
26 & 41 \% \\
76 \%\end{array}$ & ?100 & $17(50)$ & $3(9)$ & $3(9)$ & $11(32)$ & Small pathology series; all reviewed \\
\hline $\begin{array}{l}\text { Kennedy } \\
1973\end{array}$ & Female 112 & $3228 \%$ & 67 & $10(31)$ & $7(22)$ & 一 & $15(47)$ & $\begin{array}{l}\text { Women only; } \% \text { non-smokers } \\
39 \% \downarrow 12 \% \text { by } 1971\end{array}$ \\
\hline $\begin{array}{l}\text { Doll } \\
\qquad 1976\end{array}$ & Male 441 & $71 \cdot 6 \%$ & 98 & & & & & $\begin{array}{l}\text { Male doctors only; no histological } \\
\text { details }\end{array}$ \\
\hline
\end{tabular}

recently that about one third of lung cancers in non-smokers who live with smokers may be attributed to environmental smoke, and one quarter of lung cancers in non-smokers overall. $^{28}$ Many of our non-smoking patients are likely to have been passively exposed to smoke and it will clearly be essential to record this information specifically in future studies. In our series of 99 alleged non-smokers most of the 25 who were excluded had smoked previously. An accurate smoking history may be difficult to elicit; it was unobtainable in one of our patients, compared with $22-33 \%$ of patients in some earlier studies ${ }^{41213}$ (table). Misclassification of ex-smokers as non-smokers clearly remains a potential source of error. ${ }^{142833}$

Adenocarcinoma was the most common cell type found in our non-smokers, occurring in $42 \%$, three times the proportion in smokers, as in a previous British series ${ }^{12}$ (table). Although most American series have reported a higher percentage of adenocarcinoma (46\%$69 \%)^{481131419}$ (table), these apparent differences may simply reflect the well recognised difficulties of standardising the criteria for histological cell typing, particularly with adenocarcinoma. ${ }^{4426}$

Kreyberg and colleagues originally suggested that adenocarcinoma and alveolar cell lung carcinomas (their group II) were entirely unrelated to tobacco; ${ }^{67}$ but 267 of our 291 adenocarcinomas seen during the five years $(92 \%)$ occurred in smokers, much like the $89 \%$ in Vincent's series. ${ }^{4}$ Furthermore, a doseresponse relationship for cigarettes has been convincingly demonstrated for adenocarcinoma. ${ }^{10}$ All the principal histological cell types were represented in this large series of non-smokers, including squamous carcinoma in $32 \%$ and small cell carcinoma in $15 \%$. Neither can therefore be considered "rare" in non-smokers with cancer; we agree with Kabat $^{14}$ and others ${ }^{81012}$ that the Kreyberg hypothesis should now be firmly discarded.

Differentiating primary from secondary tumours may be difficult whether clinical or histological criteria are used. Any diagnosis of lung cancer based simply on pleural or lymph node biopsy is suspect, whether in smokers or non-smokers, particularly if the cell type is adenocarcinoma. ${ }^{34}$ As primary lung cancer in the lifelong non-smoker is uncommon the diagnosis should always be questioned.

We thank Mrs Lydia Scott and Mrs Helen O'Neill, secretary of the Edinburgh Lung Cancer Group, for typing the manuscript and Mrs $R$ Rose for collating the data. They have been supported by the Scottish Chest, Heart, and Stroke Association and the Melville Trust. We are most grateful to Dr I Kemp, Miss A Munro, Miss H Rae, and Mrs K Aitkenhead of the South East Scotland Cancer Registry and our colleagues in the hospital pathology laboratories and surgical and medical units.

1 Doll R, Hill AB. A study of the aetiology of carcinoma of the lung. BMJ 1950;ii:739-48.

2 Wynder EL, Graham AE. Tobacco smoking as a possible aetiology factor in bronchogenic carcinoma: a study of 684 proved cases. JAMA 1950;143:329-36.

3 Doll R, Peto R. Mortality in relation to smoking: 20 years' observations on male British doctors. BMJ 1976;ii: 1525-36.

4 Vincent RG, Pickren JW, Lane WW, et al. The changing histopathology of lung cancer. A review of 1682 cases. Cancer 1977;39:1647-56.

5 Doll R, Peto R. The causes of cancer: quantitative estimates of avoidable risks of cancer in the United States today. $J$ Natl Cancer Inst 1981;66:1 192-308.

6 Kreyberg L. The significance of histological typing in the study of the epidemiology of primary epithelial lung tumours: a study of 466 cases. $B r J$ Cancer 1954;8: 199-207.

7 Doll R, Hill AB, Kreyberg L. The significance of cell type in relation to the aetiology of lung cancer. $B r J$ Cancer 
$1957 ; 11: 43-8$.

8 Yesner R, Gelfman NA, Feinstein AR. A reappraisal of histopathology in lung cancer and correlation of cell type with antecedent cigarette smoking. Am Rev Respir Dis 1973;107:790-7.

9 Auerbach O, Garfinkel L, Parks VR. Histological types of carcinoma in relation to smoking habits, year of diagnosis and sites of metastases. Chest 1975;63:382-7.

10 Weiss W, Boucot KR, Seidman H, Carnahan WJ. Risk of lung cancer according to histological type and cigarette dosage. JAMA 1972;222:799-801.

11 Cooper DA, Crane AR, Boucot KR. Primary carcinoma of the lung in non-smokers. Arch Environ Health 1968;16: 398-400.

12 Kennedy A. Relationship between cigarette smoking and histological type of lung cancer in women. Thorax 1973; 28:204-8.

13 Beamish J, Stein A, Andrews JL. Changing epidemiology of lung cancer: increasing incidence in women. Med Clin North Am 1975;59:315-25.

14 Kabat GC, Wynder EL. Lung cancer in non-smokers. Cancer 1984;53:1214-21.

15 Jindal SK, Malik SK, Datta BN. Lung cancer in Northern India in a relation to age, sex and smoking habits. Eur $J$ Respir Dis 1987;70:23-8.

16 Ashley DJB, Davies HD. Lung Cancer in women. Thorax 1969;24:446-9.

17 Belcher JR. The changing pattern of bronchial carcinoma. Br J Dis Chest 1975;69:247-58.

18 Wynder EL, Berg JW. Cancer of the lung among nonsmokers. Cancer 1967;20:1161-72.

19 Wynder EL, Goodman MT. Smoking and lung cancer: some unresolved issues. Epidemiol Rev 1983;5:177-207.

20 Enstrom JE. Rising lung cancer mortality among nonsmokers. J Natl Cancer Inst 1979;62:755-60.
21 Office of Population Censuses and Surveys. Mortality statistics 1988. London: HMSO, 1990.

22 Registrar General Scotland. Annual report 1988. A report of the Government Statistical Service. Edinburgh: HMSO 1989.

23 Sudlow MF. Lung cancer in South East Scotland. Eur Respir Dis 1982;63(suppl 125):20.

24 Capewell S, for Edinburgh Lung Cancer Group. Patients presenting with lung cancer in South East Scotland. Thorax 1987;42:853-7.

25 American Thoracic Society. Clinical staging of primary lung cancer. Am Rev Respir Dis 1983;127:659-64.

26 Lamb D. Histological classification of lung cancer [editorial]. Thorax 1984;39:161-5.

27 Janerich DT, Thompson WD, Varela LR, Greenwald P, Chorost S. Lung cancer and exposure to tobacco smoke in the household. N Engl J Med 1990;323:632-6.

28 Wald JN, Nanchahal K, Thompson SG, Cuckle HS. Does breathing other people's tobacco smoke cause lung cancer? $B M J$ 1986;293:1217-22.

29 Capewell S, Sudlow MF, on behalf of the Edinburgh Lung Cancer Group. Performance and prognosis in patients with lung cancer. Thorax 1990;45:951-6.

30 Auerbach O, Garkinkel L, Parks VR. Scar cancer of the lung: increase over a 21 year period. Cancer 1979;43: 636-42.

31 Hinds MW, Cohen HI, Kolonel LW. Tuberculosis and lung cancer risk in non-smoking women. Am Rev Respir Dis 1982;125:775-8.

32 Rylander R. Environmental tobacco smoke and lung cancer. Eur J Respir Dis 1984;Suppl 133:127-33.

33 Lee PN. Misclassification as a factor in passive smoking risk. Lancet 1986;ii:867.

34 Anonymous. Chasing the unknown primary [editorial]. $B M J$ 1980;281:1232. 